\title{
Moleküler markörler kullanarak çerezlik kabaklarda (Cucurbita pepo L.) saflık düzeylerinin tahmin edilmesi
}

Estimation of purity levels of pumpkin genotypes (Cucurbita pepo L.) using molecular marker

\author{
Neslihan ASLAN ${ }^{1}$ (D) , Ömer Faruk COŞKUN ${ }^{2}$ iD , Akife DALDA ŞEKERCi ${ }^{1}$ (D) Osman GÜLŞEN ${ }^{1}$ (D) \\ ${ }^{1}$ Erciyes Üniversitesi, Ziraat Fakültesi, Bahçe Bitkileri Bölümü, Talas-Kayseri, Türkiye. \\ ${ }^{2}$ Hatay Mustafa Kemal Üniversitesi, Ziraat Fakültesi, Bahçe Bitkileri Bölümü, Antakya-Hatay, Türkiye.
}

\section{MAKALE BILGISI / ARTICLE INFO}

\section{Makale tarihçesi / Article history:}

DOI: $10.37908 /$ mkutbd.995779

Geliş tarihi /Received:15.09.2021

Kabul tarihi/Accepted:20.10.2021

\section{Keywords:}

Genetic diversity, dominance, codominance, heterozygosity.

\footnotetext{
Corresponding author: Ö. Faruk COŞKUN

$\bowtie$ : omerfaruk.coskun@mku.edu.tr
}

\section{Ö Z E T / A B S TR A C T}

\footnotetext{
Atıf / Citation: Aslan N, Coşkun ÖF, Dalda Şekerci A, Gülşen O (2021) Moleküler markörler kullanarak çerezlik kabaklarda (Cucurbita pepo L.) saflık düzeylerinin tahmin edilmesi. MKU. Tar. Bil. Derg. 26(3) : 759-769. DOI: $10.37908 /$ mkutbd.995779
}

\section{GiRiş}

Kabakgiller, Türkiye'de genetik çeşitlilik bakımından önemli bir yere sahip olan (Sarı ve ark., 2008), ekonomik olarak değerli sebze türlerini içeren bitki familyasıdır. Cucurbita cinsi içerisinde bulunan kabaklar meyve morfolojisi bakımından geniş bir varyasyon göstermektedir. Cucurbita cinsi içinde ekonomik olarak önemli üç tür bulunmaktadır: $C$. pepo, $C$. maxima ve $C$. moschata (Paris, 2005). Cucurbita pepo L. yaygın olarak yetiştirilen çerezlik kabak türüdür ve genellikle yemeklik kabaklardan çerezlik kabak beklentilerine uygun tiplerin 
seçilip çoğaltılmasıyla üretimi yapılmaktadır. Ayrıca az miktarda bal kabağı (C. moschata Pour.) ve kestane kabağı (C. maxima Duch.) tohumları da çerezlik olarak kullanılmaktadır (Yanmaz ve ark., 2008).

Kabak tohumları insan beslenmesi açısından oldukça önemli besin öğelerine sahiptir. Protein, yağ, mineral maddeler ve aminoasitler yönünden zengindir (Yanmaz ve Düzeltir, 2004). Minerallerden potasyum (\%0.03), kalsiyum (\%0.02), magnezyum $(\% 0.1)$ ve fosfor $(\% 0.01)$ ihtiva etmektedir. Kabak tohumları protein (\%33-36), doymamış yağ asitleri (\%35-47), karbonhidrat (\%37) ve $\mathrm{E}$ vitamini yönünden oldukça zengindir. Ayrıca kolesterol düşürücü bir hidrakarbon olan 'squalene' kabak tohumlarında bulunmaktadır (Ermiş, 2010).

Dünya Gıda ve Tarım Örgütü (FAO) tarafından yayınlanan istatistiklerde çerezlik kabak konusunda herhangi bir veri bulunmayıp sadece yemeklik kabak konusunda istatistiksel veriler sunulmaktadır. Dünya'da 2.078.450 hektar alanda 27.449.48 ton yemeklik kabak üretimi yapılmaktadır. Dünya kabak üretiminde Çin 7.996.362 ton ile birinci sırada yer alırken bu sırayı Hindistan (5.142.812 ton), Rusya (1.165.834), Ukrayna (1.164.660) ve Amerika (1.091.121 ton) takip etmektedir. Türkiye ise yemeklik kabak üretiminde dünyada 9. sıradadır (580.624 ton) (FAO, 2017). Türkiye'de 2018 yılı toplam çerezlik kabak üretimi 55043 tondur (TUiK, 2018).

Çerezlik kabak üretiminde birörnek şekil ve büyüklükte tohum üretmek oldukça önemlidir. Çerezlik olarak tüketilecek tohumlar büyüklüklerine göre ayrılarak satışa sunulmaktadır. Ek olarak tohumluk olarak kullanılacak tohumlar için de homojenlik ve safiyet önem arz etmektedir. Bu şekilde tohum üretiminde hibrit tohumlar beklentileri rahatlıkla karşılayabilir. Hibrit tohum üretiminde saf ebeveynlerin kullanılması son derece önemlidir. Genetik olarak saf olmayan ebeveynlerin hibrit tohum üretiminde kullanılması sakıncalıdır. Saflık düzeylerini tahmin etmenin pratik bir yolu bulunmamakla birlikte, arazide tohumlardan elde edilen bitkiler arasındaki morfolojik özellikleri dikkate alarak genetik açılım olup olmadığı anlaşılabilmektedir. Tohum safiyetini tespit etmede önemli bir yöntem de moleküler markör teknikleridir.

Moleküler markörler, DNA dizilerinin farklılıklarını ortaya çıkaran ve genotiplerde istenilen bir geni veya özelliği izlemek için kullanılan markörlerdir. Bu markörler, gözlenebilir karakterlere ve temeli proteine dayanan markörlere göre oldukça güvenilirdir. Sayıları fazla olup çevreden etkilenmezler. Bitki gelişiminin herhangi evresinde gözlenebilir ve lokuslar arasında etkileşim oluşmamaktadır. Bu nedenlerle DNA markörleri ıslah çalışmalarında bitki materyallerinin seleksiyonu için en iyi araçtır (Ovesna ve ark., 2002). Farklı DNA markör teknikleri kullanılarak bitki türlerinde genetik çalışmalar başarılı bir şekilde gerçekleştirilmiştir (Coşkun ve ark., 2017; Uzun ve ark., 2017; Pınar ve ark., 2017a; Pınar ve ark., 2017b; Bulut ve ark., 2018; Karaman ve ark., 2018; Tecirli ve ark., 2018; Uzun ve ark., 2020).

Mikrosatellitler, ökaryotik genomlar boyunca dağılmıştır. SSR'lar yüksek oranda polimorfik olduklarından bitkiler hakkında oldukça fazla bilgi vermektedir. Bunun yanında genellikle kodominant markör vermesi ve PCR kolaylığı da kullanım oranını arttırmaktadır (Röder ve ark., 1995). ISSR tekniğinde iki mikrosatellit arası bölge çoğaltılabilmektedir. ISSR, genellikle dominant markördür ve en önemli avantajı dizi bilgisi gerekmeksizin primer dizaynı yapılabilmesidir (Joshi ve ark., 2000). Yüksek oranda polimorfizm ve üretkenlik göstermesinden dolayı ISSR analizleri genetik benzerlik, gen haritalama ve taksonomi çalışmalarında kullanılabilmektedir (Gupta ve ark., 1994; Zietkiewicz ve ark., 1994). Bazı çerezlik kabak genotiplerinde genetik karakterizasyonun belirlenmesi amacıyla ISSR (Katzir ve ark., 1998; Katzir ve ark., 2000; İnan ve ark., 2012; Esmailnia ve ark., 2015) ve SSR (Katzir ve ark., 2000; Barzegar ve ark., 2013; Xanthopoulou ve ark., 2014; Xanthopoulou ve ark., 2017) teknikleri önceki çalışmalarda kullanılmıştır. Çerezlik kabakta hibrit tohum üretiminde saf ebeveynlerin kullanılması son derece önem arz etmektedir. Moleküler markör tekniklerinin kullanımıyla ebeveynlerin saflık düzeylerinin belirlenmesi mümkün olabilir. Bu çalışmada moleküler markörler yardımıyla S1, S2, S3 ve S0 (kendilenmemiş) kademesindeki kabakların dominant ve kodominant markörler kullanarak saflık düzeylerinin belirlenmesi ve heterozigotluk arasındaki ilişkiyi tahmin etmek amaçlanmıştır.

\section{MATERYAL ve YÖNTEM}

\section{Bitkisel materyal}

Bu araştırma, Erciyes Üniversitesi, Ziraat Fakültesi Bahçe Bitkileri Bölümü Laboratuvarında yürütülmüştür. Islah çalışmaları devam etmekte olan çerezlik kabak koleksiyonundan geliştirilen S1 kademesinden 15 adet, S2 kademesinden 15 adet, S3 kademesinden 15 adet ve kendilenmemiş SO kademesindeki bitkilerden rasgele $15 \mathrm{er}$ adet örnek alınmıştır. Toplamda 60 örnekle çalışılmıştır. Çalışmaya konu olan genotipler çerezlik kabak üretiminin yoğun olarak yapıldığı Develi ve Tomarza ilçelerinden derlenen koleksiyona ait genotiplerdir. Toplamda 60 adet genotipin DNA'sı kullanılarak çalışmalar yürütülmüş olup Çizelge $1^{\prime}$ de sunulmuştur. 
Çizelge 1. Farklı kademelerdeki çerezlik kabak genotiplerinin isim, kodları ve saflık düzeyleri (S0, S1, S2 ve S3). Table 1. Names, codes and purity levels of pumpkin genotypes at different levels (SO, S1, S2 and S3).

\begin{tabular}{|c|c|c|c|c|c|c|c|}
\hline \multicolumn{2}{|c|}{ S1'ler } & \multicolumn{2}{|c|}{ S2'ler } & \multicolumn{2}{|c|}{ S3'ler } & \multicolumn{2}{|c|}{ So'lar } \\
\hline 1 & T17-S1-2 & 22 & T33-S2-4 & 37 & D26-4-S3-8 & 52 & 52 \\
\hline 2 & T55-S1-3 & 23 & T46-S2-9 & 38 & D24-1-S3-9 & 53 & 53 \\
\hline 3 & T38-S1-7 & 24 & T41-S2-1 & 39 & D14-5-S3-3 & 54 & 54 \\
\hline 4 & T53-S1-5 & 25 & T34-S2-1 & 40 & D7-1-S3-1 & 55 & 55 \\
\hline 5 & T54-S1-3 & 26 & T17-S2-6 & 41 & D25-4-S3-10 & 56 & 56 \\
\hline 6 & T24-S1-10 & 27 & T22-S2-10 & 42 & D29-5-S3-5 & 57 & 57 \\
\hline 7 & T36-S1-5 & 28 & T33-S2-7 & 43 & D32-2-S3-5 & 58 & 58 \\
\hline 8 & T8-S1-5 & 29 & T39-S2-2 & 44 & D30-3-S3-3 & 59 & 59 \\
\hline 9 & T39-S1-2 & 30 & T55-S2-5 & 45 & D19-2-S3-1 & 60 & 60 \\
\hline 10 & T18-S1-4 & 31 & T45-S2-2 & 46 & D3-5-S3-8 & 61 & 61 \\
\hline 11 & T17-S1-6 & 32 & T20-S2-4 & 47 & D2-2-S3-4 & 62 & 62 \\
\hline 12 & T41-S1-10 & 33 & T3-S2-1 & 48 & D24-4-S3-8 & 63 & 63 \\
\hline 13 & T20-S1-10 & 34 & T34-S2-2 & 49 & D21-3-S3-7 & 64 & 64 \\
\hline 14 & T18-S1-6 & 35 & T20-S2-2 & 50 & D2-1-S3-9 & 65 & 65 \\
\hline 15 & T4-S1-7 & 36 & T39-S2-5 & 51 & D22-3-S3-1 & 66 & 66 \\
\hline
\end{tabular}

\section{Moleküler yöntem}

DNA İzolasyonu için Doyle ve Doyle'nin (1990) geliştirdiği DNA izolasyon yöntemi uygulanmıştır. CTAB DNA ekstraksiyon işlemi ile DNA izolasyonu sağlanmıştır. PCR reaksiyonu için toplam hacim $15 \mu$ l olarak hazırlanmıştır: $7.15 \mu$ listile su, $1.5 \mu \mathrm{l} 10 \times$ DNA polymerase buffer, 1.2 $\mu \mathrm{l}$ dNTPs $(2.5 \mathrm{mM}), 1 \mu \mathrm{l}$ primer $(5 \mathrm{mM}), 0.15 \mu \mathrm{l}$ Taq Polymerase $(1 \mathrm{U})$ ve $20 \mathrm{ng}$ DNA.

Hazırlanan PCR karışımı 36 SSR ve 12 ISSR primeri kullanılarak analiz edilmiştir. Çalışmada kullanılan SSR ve ISSR markör primerlerinin göstermiş olduğu polimorfik bantlar belirlenmiştir. Polimorfizm bilgi içeriği (PIC), her bir primer için PIC=1- $\sum(\mathrm{Pi})^{2}$ formülü ile hesaplanmıştır. Genotipler arasındaki genetik benzerlik değerleri NTSYS (Numerical Taxonomy Multivariate Analysis System) paket programı kullanılarak analiz edilmiştir. Matriks oluşturularak genetik benzerlik kats ayısı Dice (1945) yöntemine göre hesaplanmış ve UPGMA yöntemiyle bireyler arasındaki benzerlikleri gösteren dendrogram yapılmıştır.

Kodominant markör sistemi için her saflık derecesi bir uygulama gibi kabul edilerek 4 farklı (SO, S1, S2, S3) populasyonun heterozigotluk seviyesi, sahip oldukları bant sayısına göre belirlenmiştir. Heterozigotluk seviyesi ile genotiplerin sahip olduğu bant sayısı arasında doğrusal bir ilişki beklenmelidir (Gülşen ve Roose, 2001). $\mathrm{Bu}$ amaçla her lokus açısından farklı kendileme kademesindeki genotiplerin bant sayıları hesaplanmış ve DUNCAN testiyle karşılaştırılmıştır.

\section{BULGULAR ve TARTIŞMA}

\section{SSR analiz sonuçları}

Bu çalışma kapsamında 36 adet SSR primeri test edilmiş ve bunlardan, 18 adet SSR primer çifti ile 52 skorlanabilir bant elde edilmiştir. Bu primer çiftleri arasından 15 primer çiftinde polimorfizm belirlenmiş, 3 primer çifti ise (CMTm120, CMTm111, CMTm206) monomorfik (hepsi aynı) bant üretmiştir. Elde edilen toplam allel sayısı bakımından CMTp182 ( 6 adet) lokusu en fazla alleli üretmiştir. Farklı kademelerdeki kabaklardan elde edilen bant profilleri Şekil 1'de sunulmuştur. En yüksek PIC değeri (0.9) CMTm66 ve CMTp182 primer çiftlerinde, en düşük PIC değeri ise CMTm120, CMTm111 ve CMTm206 primer çiftlerinden elde edilmiştir. Michael ve ark. (2019)'nın yaptığı çalışmada 39 SSR işaretleyici kullanılmıştır. Markörlerin ortalama PIC değeri 0.57 olarak tespit edilmiştir. Çalışılan SSR primer çiftlerinin polimorfizm ve PIC değerleri Çizelge 2'de sunulmuştur. $\mathrm{Bu}$ çalışmada belirlenen değerler Michael ve ark. (2019)'nın elde ettiği değerlerden daha yüksektir. Barzegar ve ark. (2013), yaptıkları çalışmada ise 26 adet Cucurbita pepo $L$. yerel çeşidi arasında genetik çeşitliliği tespit etmek için 14 SSR primer çifti kullanmışlardır. Genetik çeşitlilik indeksi ve enformasyon indeksi kullanılarak tahmin edilen polimorfik lokus yüzdesi, orta ya da yüksek derecede genetik çeşitlilik ortaya koymuştur. Xanthopoulou ve ark. (2014), yaptıkları çalışmada sadece 4 adet mikrosatellit markör kullanarak, 36 yazlık kabak yerel çeşidi ayırt etmişlerdir. EST-SSR markörlerinin, yazlık kabakta biyoçeşitlilik değerlendirmesi gibi farklı uygulamalarda faydalı olabileceğini, en önemlisi ıslah programlarını iyileştirmek 
için kabak germplazmını yönetmede yararlı olabileceğini belirtmişlerdir.

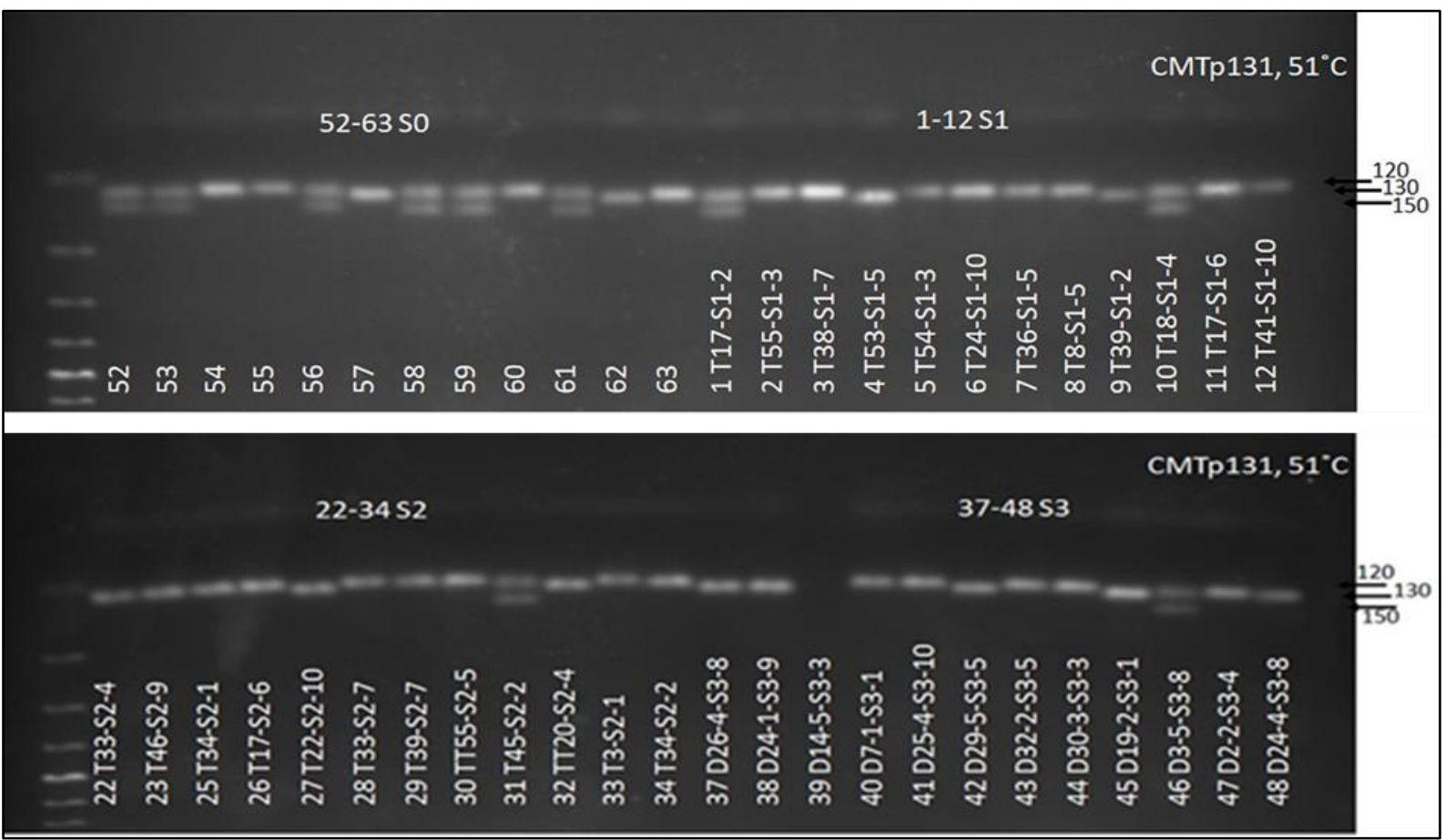

Şekil 1. CMTp131 primer çifti kullanılarak S0-S1-S2-S3 kademelerinde elde edilen bant profilleri (Standart DNA markörü: 100-1500 bç).

Figure 1. Band profiles obtained at SO-S1-S2-S3 levels using the CMTp131 primer pair (Standard DNA marker: 100$1500 \mathrm{bp})$.

Moleküler markör teknikleri karşılaştırıldığında polimorfizm düzeyi yüksek olduğundan dolayı SSR ve SNP markör teknikleri daha çok tercih edilmektedir. Katzir ve ark. (2000)'da yaptıkları çalışmada SSR tekniğinin $C$. pepo'nun akrabalık ilişkilerini ortaya koymada çok daha başarılı olduğunu belirlemişlerdir. Xanthopoulou ve ark. (2014), yaptıkları çalışmada 4 adet mikrosatellit markör kullanarak, 36 yazlık kabak yerel çeşidi ayırt etmişlerdir. Bu çalışmada da SSR markörleri oldukça zengin bir allel çeşitliliği ortaya koymuştur.

SSR tekniği ile NYSYS paket programı ile benzerlik indeksleri hesaplanarak elde edilen dendrograma göre, benzerlik katsayıları 0.64-0.93 arasında değişmiştir (Şekil 2). Ortalama benzerlik katsayısı 0.78 bulunmuştur. Bütün genotipler genetik olarak birbirlerinden farklı bulunmuştur. Dendrogram 2 ana kola ayrılmıştır. 1. ana kolda $31 S 2$ ve $26 S 2$ genotipleri yer alırken, 2 . ana kolda ise $40 S 3$ ve diğer genotipler kümelenmiştir. Geriye kalan genotiplerin tamamı bu kol içerisinde yer almaktadır. 01S1 ve 47S3 genotiplerinin birbiri ile aynı yerde konumlandığı belirlenmiştir. Birbirine en benzer genotipler 0.91 benzerlik katsayısı ile 5950 ve 39S3'dür (Şekil 2). Dendrogram grafiği sonuçlarına göre farklı kendileme kademesindeki genotiplerin birbiriyle benzerlik gösterebildiği gibi genellikle farklı oldukları tespit edilmiştir. Bu sonuç, çalışılan genotiplerin rasgele olması yönündeki öngörümüzün de doğru olduğunu ve yürütülen bu çalışmanın amacına uygun olduğunu ortaya koymaktadır.

\section{ISSR analiz sonuçları}

Bu çalışmada, 12 ISSR primeri kullanıımıştır. $\mathrm{HVH}(\mathrm{TCC})_{7}$, $\mathrm{HVH}(\mathrm{CA})_{7} \mathrm{~T}, \mathrm{DBDA}(\mathrm{CA})_{7},(\mathrm{AG})_{7} \mathrm{YC}, \mathrm{BDB}(\mathrm{CA})_{7} \mathrm{C}$ ve $(\mathrm{GT})_{8} \mathrm{YA}$ ISSR primer çiftlerinde yüksek polimorfizm görülmüş, 2 primer çifti monomorfik bantlaşma göstermiştir. Toplamda 60 bant elde edilmiş ve 36'sı polimorfiktir. Elde edilen toplam allel sayısı bakımından $\mathrm{HVH}(\mathrm{TCC})_{7}(18$ adet) primeri en fazla alleli üretmiştir. Farklı kademelerdeki çerezlik kabakların DNA'ları ile elde edilen bant profilleri Şekil 3'te sunulmuştur. En yüksek PIC değeri 0.4 ile $\mathrm{HVH}(\mathrm{TCC})_{7}, \mathrm{HVH}(\mathrm{CA})_{7} \mathrm{~T}$ ve $\mathrm{BDB}(\mathrm{CA})_{7} \mathrm{C}$ primer çiftlerinde, en düşük $\mathrm{PIC}$ değeri ise (CA)8R ve $(\mathrm{CT})_{8} \mathrm{TG}$ primer çiftlerinde elde edilmiştir (Çizelge 3). İnan ve ark. (2012)'nın yaptıkları çalışmada 8 adet ISSR primer çifti kullanarak 6 bant elde etmiştir ve bütün bantların polimorfik olduğunu bulmuşlardır. Bu çalışmadan elde edilen primer başına lokus sayısı daha fazladır. 
Esmailnia ve ark. (2015)'ı yaptıkları çalışmalarında 17 ISSR primer çiftinden $11^{\prime}$ inin toplam 283 bant verdiğini ve bunların 263'ünün (\%92.93) polimorfik olduğu gözlenmiştir. Ortalama polimorfizm bilgi içeriği (PIC) 0.3 olarak tahmin edilmiştir.

Çizelge 2. Gaziantep ili zeytin bahçesi topraklarının bazı fiziksel ve kimyasal özellikleri ve alınabilir bor içerikleri Table 2. Polymorphism and PIC values obtained from SSR primer pairs

\begin{tabular}{ccccc}
\hline Lokus & Toplam bant sayısı & Polimorfik bant sayısı & \% Polimorfizm & PIC değeri \\
\hline CMT131 & 3 & 3 & 100 & 0.80 \\
CMTmC67 & 3 & 3 & 100 & 0.70 \\
CMTm120 & 1 & 0 & 0 & 0.00 \\
CMTp46 & 3 & 3 & 100 & 0.80 \\
CMTp174 & 3 & 3 & 100 & 0.70 \\
CMTm130 & 2 & 2 & 100 & 0.60 \\
CMTm84 & 5 & 4 & 80 & 0.60 \\
CMTm144 & 5 & 3 & 100 & 0.70 \\
CMTm66 & 3 & 4 & 100 & 0.90 \\
CMTmC14 & 4 & 3 & 75 & 0.70 \\
CMT182 & 4 & 6 & 100 & 0.90 \\
CMTm68 & 6 & 3 & 100 & 0.80 \\
CMTm111 & 3 & 0 & 0 & 0.00 \\
CMTm206 & 1 & 0 & 0 & 0.00 \\
CMTmC34 & 1 & 1 & 100 & 0.00 \\
CMTp125 & 1 & 4 & 100 & 0.60 \\
CMTp247 & 4 & 3 & 100 & 0.80 \\
CMTm187 & 3 & 2 & 100 & 0.60 \\
\hline Average PIC value & 2 & & & 0.57 \\
\hline
\end{tabular}




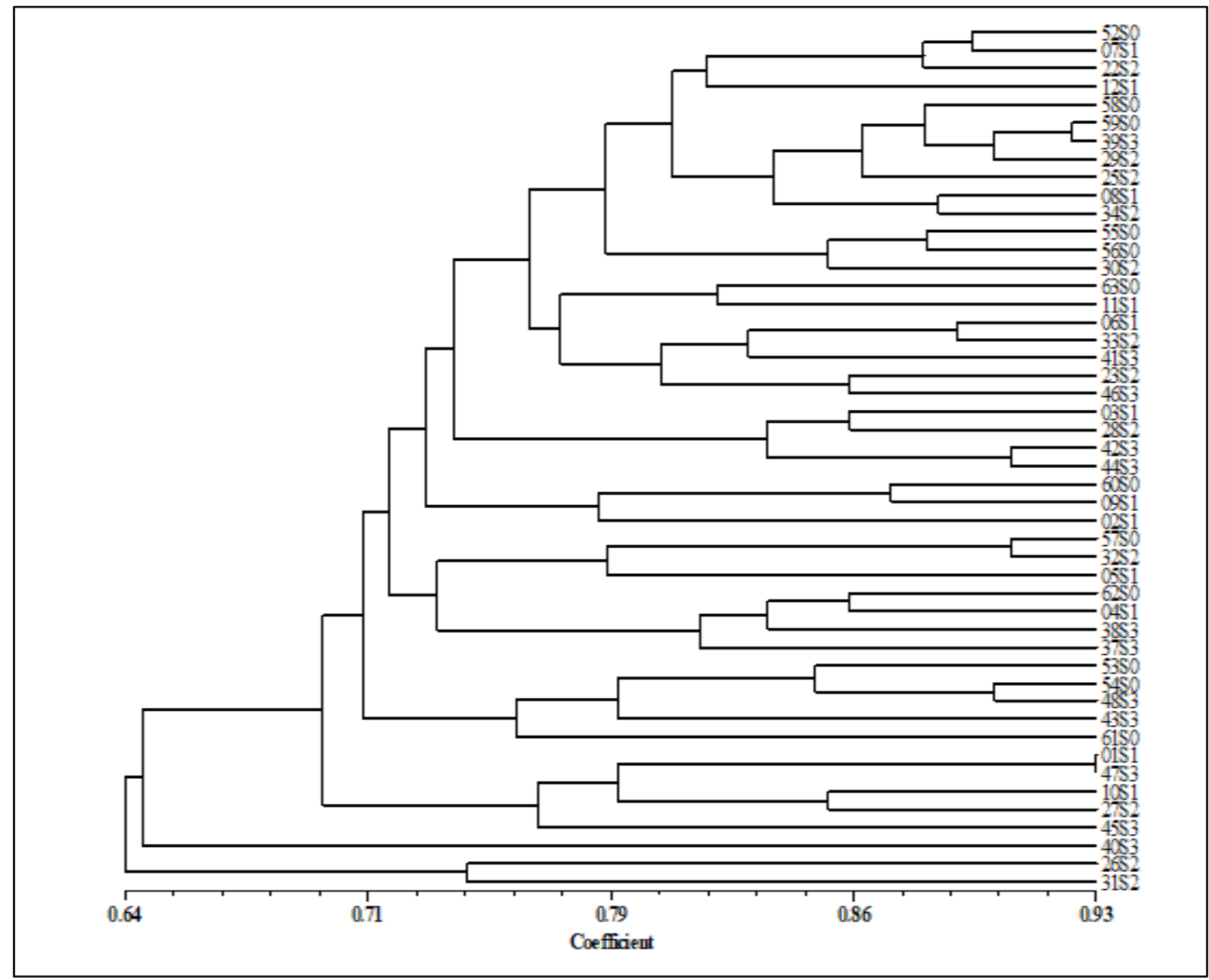

Şekil 2. SSR verilerinden elde edilen benzerlik indekslerinin SHAN modülünde kullanılmasıyla oluşturulmuş dendrogram.

Figure 2. Dendrogram created by using similarity indexes obtained from SSR data in SHAN module.

Primer çiftleri arasında en yüksek polimorfik bant ve PIC değerini ISSR15'te elde etmişlerdir. ISSR15 primer çiftini genetik çeşitliliği araştırmak için en uygun ve ayırt edici primer çifti olarak kabul etmişlerdir. Bu çalışmalar bizim çalışmamızla uyum içerisindedir.Dendrograma göre benzerlik katsayıları 0.85-0.98 arasında değişmiştir. Ortalama benzerlik katsayısı 0.91 olmuştur (Şekil 4). Dendrogramda 1. ana kolda 4353 ve 3352 genotipleri yer almaktadır. 2. ana kolda ise $48 \mathrm{~S} 3$ ve $04 \mathrm{~S} 1$ genotipleri diğerlerinden ayrı kümelenmiştir. Dendrograma göre 5350 ve 57S0 genotipleri birbiri ile aynı bulunmuştur. Dendrogramda görüldüğü üzere farklı kendileme kademesindeki genotipler benzerlik gösterebilmektedir. Inan ve ark. (2012)'nın yaptıkları çalışmada ISSR analizinde, genetik benzerlik katsayısını 0.07-0.96 arasında bulmuşlardır. Ferriol ve ark. (2003), İspanya'nın yerel genotiplerinden oluşan ve ticari olarak üretilen $C$. pepo'ya ait 69 genotipi morfolojik ve moleküler açıdan değerlendirmişlerdir. UPGMA metodu kullanılarak cluster analizi yapılmıştır ve bu 2 markör sistemi kullanılarak genotipler iki alt türe ayrılmıştır. Bizim çalışmamıza ait dendogramlarda ise belirgin bir gruplaşma görülmemiştir. Çalışmada kullanılan örnekler yukarıda açıklandığı gibi farklı kademelerden ve her birinden $15^{\prime}$ er adet olmak üzere toplamda 60 adet rasgele örnek seçilip analizlerde kullanılmıştır. Bu sonuç kullanılan materyallerin yürütülen bu çalışmanın amacına uygun olduğunu ortaya koymuştur. 


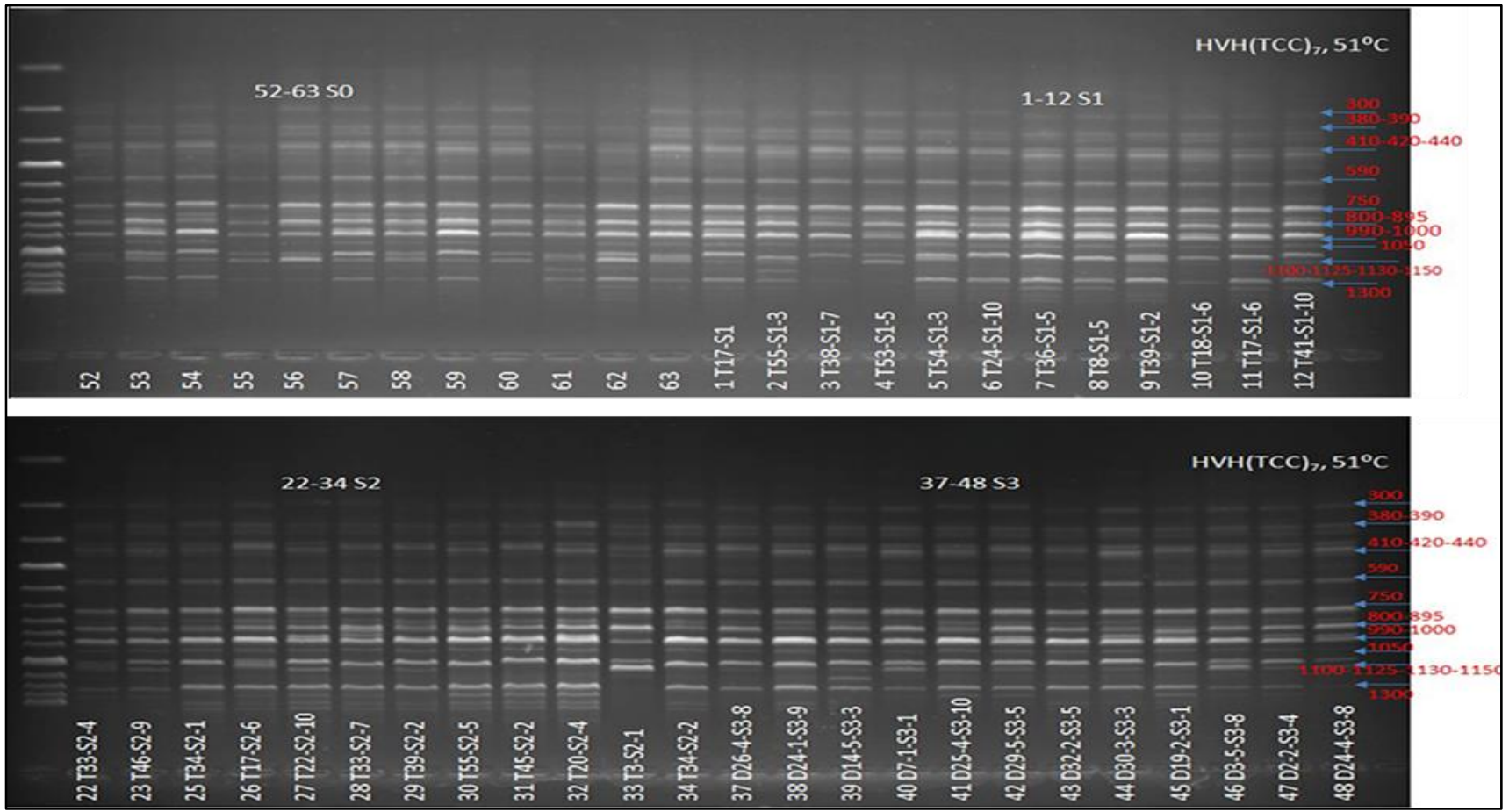

Şekil 3. HVH(TCC) 7 primer çifti kullanılarak S0-S1-S2-S3 kademelerinde elde edilen bant profilleri (DNA markörü: 1001500 bç).

Figure 3. Band profiles obtained at SO-S1-S2-S3 levels using HVH(TCC) ${ }_{7}$ primer pair (Standard DNA marker: 100-1500 bp).

Çizelge 3. Çalışılan ISSR primer çiftlerinin polimorfizm ve PIC değerleri Table 3. Polymorphism and PIC values obtained from ISSR primer pairs

\begin{tabular}{ccccc}
\hline Lokus & Toplam bant sayısı & Polimorfik bant sayıs & \% Polimorfizm & PIC değeri \\
\hline $\mathrm{HVH}(\mathrm{TCC})_{7}$ & 18 & 12 & 67 & 0.40 \\
$\mathrm{HVH}(\mathrm{CA})_{7} \mathrm{~T}$ & 13 & 8 & 61 & 0.40 \\
$\mathrm{DBDA}(\mathrm{CA})_{7}$ & 8 & 5 & 62 & 0.20 \\
$(\mathrm{CA})_{8} \mathrm{R}$ & 3 & 0 & 0 & 0.00 \\
$(\mathrm{AG})_{7} \mathrm{YC}$ & 8 & 3 & 37 & 0.20 \\
$\mathrm{BDB}(\mathrm{CA})_{7} \mathrm{C}$ & 7 & 6 & 86 & 0.40 \\
$(\mathrm{GT})_{8} \mathrm{YA}$ & 2 & 2 & 100 & 0.20 \\
$(\mathrm{CT})_{8} \mathrm{TG}$ & 1 & 0 & 0 & 0.00 \\
\hline Average PIC value & & & 0.20 \\
\hline
\end{tabular}




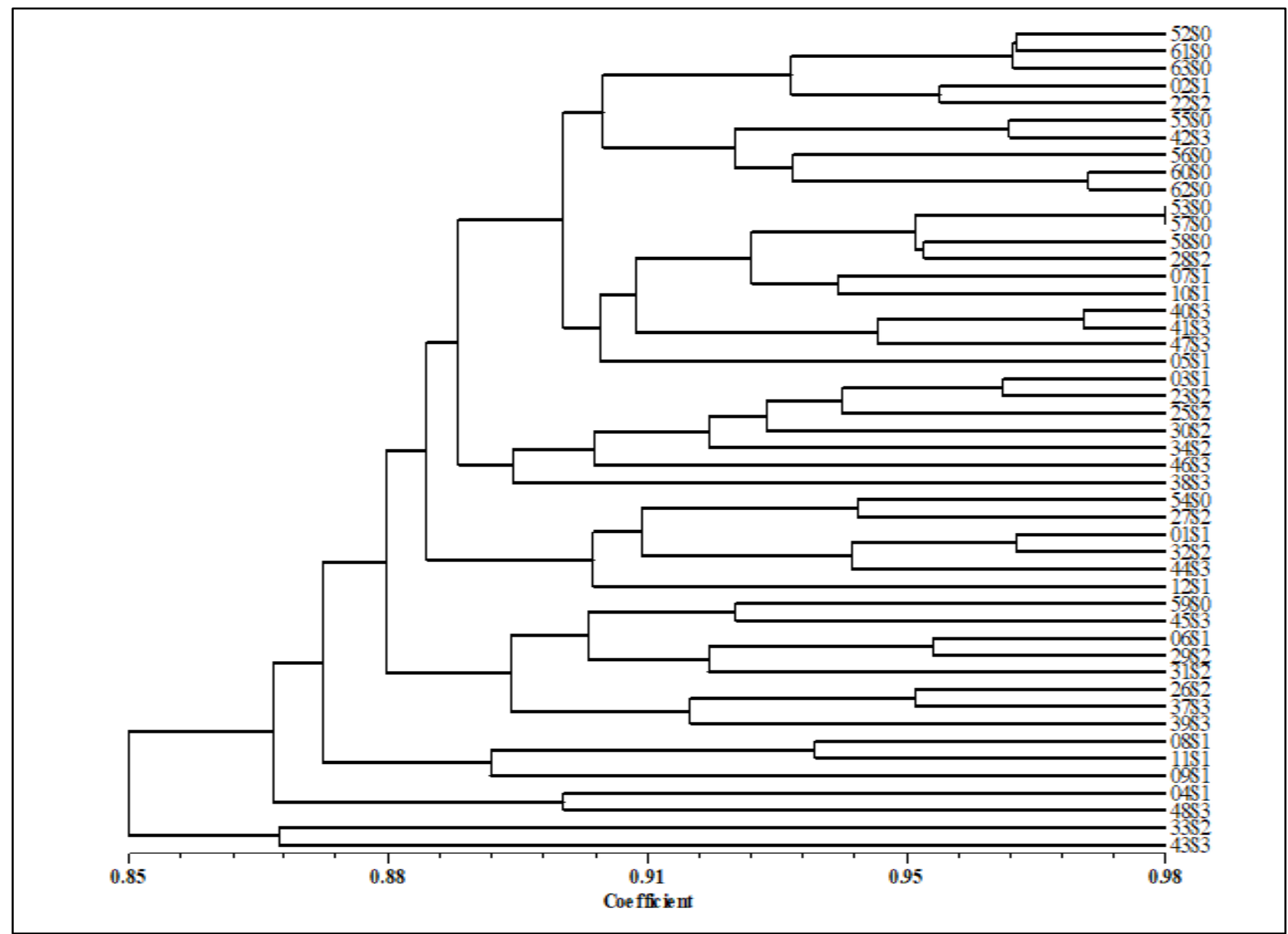

Şekil 4. ISSR verilerinden elde edilen benzerlik indekslerine göre SHAN modülünde oluşturulmuş dendrogram Figure 4. Dendrogram created by using similarity indexes obtained from ISSR data in SHAN module.

\section{Heterozigotluk analizleri}

SSR ve ISSR analizleri sonucu, farklı kademelerdeki çerezlik kabakların heterozigotluk oranları hesaplanmıştır. Her iki analiz sonucunda da kademeler arası heterozigotluk giderek azalmıştır. En fazla heterozigot bant sayısı so kademesinde, en az heterozigot bant sayısı S3 kademesinde gözlenmiştir. Çizelgedeki verilere bakıldığında ortalama ve medyan değerleri çalışmadaki beklentiyi daha iyi karşılamaktadır. Gülşen ve Roose (2001)'a göre kodominant markörler için melezlerde daha fazla bant gözlenmektedir çünkü ebeveynler aynı bölgede farklı aleller için homozigotsa, melez her iki allele de sahip olacaktır. Dominant markörler için melezlerde daha fazla sayıda bant beklenmektedir çünkü ana taksonların farklı lokuslarda farklı aleller için homozigot olması muhtemeldir ve hibridin bu tür lokuslarda bandın baskın genin fenotipine sahip olması beklenir. Ayrıca bütün Cucurbit'lerde olduğu gibi kabak bitkisi yabancı tozlanan bir türdür ve bu da genetik çeşitliliği arttıran bir unsurdur. SSR ve ISSR analizleri sonucu yapılan DUNCAN analizinde kademeler arası heterozigotluk oranının azaldığı homozigotlaşmanın arttığı görülmüştür. Bu sonuçlar çalışmanın sonucunu doğrular niteliktedir. SSR verileri ile yapılan DUNCAN analizi genotipler arasındaki farkların 0.0001 düzeyinde önemli olduğunu göstermektedir. Bu bulgular Gülşen ve Roose (2001) tarafından bulunan bulgularla da uyum içerisindedir. ISSR verileri ile yapılan DUNCAN analizi genotipler arasındaki farkların 0.0089 düzeyinde önemli olduğunu ifade etmektedir.

Çizelge 4. SSR ve ISSR analizleri sonucu heterozigotluk oranları

Table 4. Heterozygosity rates as a result of SSR and ISSR analyzes

\begin{tabular}{ccccccccc}
\hline & \multicolumn{4}{c}{ SSR analizleri } & \multicolumn{4}{c}{ ISSR analizleri } \\
\cline { 2 - 9 } & S0 & S1 & S2 & S3 & S0 & S1 & S2 & S3 \\
\hline Ortalama & 23.0 & 22.3 & 21.2 & 20.3 & 49.1 & 48.3 & 47.9 & 46.4 \\
Mod & 22 & $23-22$ & $22-21$ & 21 & 49 & $49-48-47$ & 49 & 48 \\
Medyan & 23 & 22 & 21 & 20 & 49 & 48 & 49 & 46 \\
\hline
\end{tabular}


Çizelge 5. SSR ve ISSR analizleri sonucu yapılan DUNCAN analizi

Table 5. DUNCAN analysis as a result of SSR and ISSR analyzes

\begin{tabular}{cccc}
\hline & SSR & \multicolumn{2}{c}{ ISSR } \\
\hline Duncan Gruplaması & Bant Sayısı Ortalaması & Duncan Gruplaması & Bant Sayısı Ortalaması \\
\hline S3-A & 202.500 & S3-A & 464.167 \\
S2-A & 211.667 & S2-BA & 479.167 \\
S1-B & 222.500 & S1-B & 483.333 \\
SO-B & 230.000 & SO-B & 491.667 \\
Pr $>$ F & $<0.0001$ & Pr $>$ F & 0.0089 \\
\hline
\end{tabular}

Sonuç olarak, SSR ve ISSR primerlerinin çerezlik kabak çalışmalarında kullanılabilir olduğu görülmektedir. Çalışma sonucunda elde edilen verilere göre, yüksek polimorfizm nedeniyle saflaştırma çalışmalarında SSR primer çiftlerinin daha etkin olduğu saptanmıştır. Başarıı bulunulan primer çiftleri gelecek çalışmalar için yol gösterici niteliktedir. Gelecekte yapılabilecek ilişki haritalaması, safiyet testlemesi ve yeni markör geliştirme çalışmalarında kullanılabilecektir. Uzun süren ıslah çalışmalarında, homozigotluğu gözlemenin en yaygın yöntemi morfolojik özelliklerde gözlenen devamlı varyasyon olmaktadır. Yapılan bu çalışma, saflaştırmadaki başarının izlenebilirliğini, moleküler teknikler yardımıyla desteklemeye olanak sağlamıştır. Yapılan analizler sonucunda S0, S1, S2 ve S3 kademeleri arasında heterozigot bant sayısı giderek azalan bir ivme göstermiştir. En fazla heterozigot bant sayısı SO kademesinde ve en az heterozigot bant sayısı S3 kademesinden elde edilmiştir. Bu durum saflaşma oranı artıkça heterozigot bant sayısının azaldığını göstermektedir. Elde edilen sonuç arazi koşullarında gözlenen morfolojik özellikleri destekler niteliktedir. Genel olarak çalışma sonuçları moleküler markörlerin heterozigotluk seviyelerini tahmin etmede ve kendileme çalışmalarında kontrol aracı olarak başarılı bir şekilde kullanılabileceğini ortaya koymuştur. Özellikle başarılı/etkin bulunan SSR primerlerin Islah programlarında yer verilmesi tavsiye edilebilir.

\section{ÖZET}

Amaç: Bu çalışmada moleküler markörler kullanılarak çerezlik kabaklarda (Cucurbita pepo L.) saflık düzeylerinin tahmin edilmesi amaçlanmıştır.

Yöntem ve Bulgular: Dominant ve kodominant moleküler markör teknikleri (simple sequence repeats, SSR ve inter-simple sequence repeats, ISSR) yardımıyla SO (hiç kendileme yapılmamış), S1, S2 ve S3 kademesindeki kabakların saflık düzeyleri ile heterozigotluk arasındaki ilişki tahmin edilmiştir. SSR analizleri sonucunda CMTp182 ve CMTm66 primerlerinde ortalama PIC değeri (0.9) ve gen çeşitliliği
(0.10) belirlenmiştir. ISSR analizleri sonucunda $\mathrm{HVH}(\mathrm{CA})_{7} \mathrm{~T}, \mathrm{HVH}(\mathrm{TCC})_{7}$ ve $\mathrm{BDB}(\mathrm{CA})_{7} \mathrm{C}$ primerlerinde en yüksek ortalama PIC değeri (0.4) bulunmuş olup gen çeşitliliği sırasıyla $0.61,0.67$ ve 0.86 olarak tespit edilmiştir. Bu çalışmada kullanılan markör verimliliğinin bir ifadesi olan PIC değerleri karşılaştırıldığında SSR primerlerinin ortalama PIC değeri 0.57 bulunurken, ISSR markörlerinin ortalama PIC değeri ise 0.2 olarak hesaplanmıştır. Saflaşma çalışmalarında SSR primerlerinin yüksek polimorfizm göstermeleri nedeniyle daha etkin olduğu saptanmıştır.

Genel Yorum: Yapılan analizler sonucunda farklı kademeler (S0, S1, S2 ve S3) arasında heterozigot bant sayısı giderek azalan bir eğilim göstermiştir. En fazla heterozigot bant sayısı SO kademesinden ve en az heterozigot bant sayısı S3 kademesinden elde edilmiştir. $\mathrm{Bu}$ durum saflaşma oranı arttıkça heterozigot bant sayısının azaldığını göstermektedir. Başarılı bulunulan primerlerin saflık düzeyi belirleme çalışmalarında kullanılabileceği sonucuna varılmıștır.

Çalışmanın Önemi ve Etkisi: Bitkilerde saf hatların elde edilmesi ıslah çalışmaları için çok önemli bir etkendir. Çerezlik kabakta hibrit tohum üretiminde saf ebeveynlerin kullanılması önemlidir ve bitkilerde saflık düzeylerini tahmin etmenin pratik bir yolu bulunmamaktadır. Arazide tohumlardan elde edilen bitkiler arasındaki morfolojik özellikleri dikkate alarak genetik açılım olup olmadığı anlaşılabilmektedir. Moleküler markörlerin ebeveynlerin saflık düzeylerinin belirlenmesinde kullanılabilirliğinin belirlenmiş olması önemlidir.

Anahtar Kelimeler: Genetik çeşitlilik, dominant, kodominant, heterozigotluk.

\section{TEŞEKKÜR}

Bu çalışmayı FYL-2018-7607 kodlu proje ile destekleyen Erciyes Üniversitesi Bilimsel Araştırma Projeleri Koordinatörlüğü'ne ve çalışmalara katkı sağlayan Kayseri Şeker Fabrikası'na teşekkür ederiz. 


\section{ÇIKAR ÇATIŞMA BEYANI}

Yazarlar çalışma konusunda çıkar çatışmasının olmadığını beyan eder.

\section{ARAŞTIRMACILARIN KATKI ORANI BEYANI}

Yazarlar çalışmaya eşit oranda katkı sağlamış olduklarını beyan eder.

\section{KAYNAKLAR}

Anonymous (2017) FAO Bitkisel Üretim İstatistikleri. http://www.fao.org/faostat/en/\#data/QC/visualize (Erişim Tarihi: 7 Temmuz 2021).

Anonymous (2018) TUiK Bitkisel Üretim İstatistikleri. https://biruni.tuik.gov.tr/medas/?kn=92\&locale $=$ tr (Erişim Tarihi: 25 Temmuz 2021).

Barzegar R, Peyvast G, Ahadi AM, Rabiei B, Ebadi AA, Babagolzadeh A (2013) Biochemical systematic, population structure and genetic variability studies among Iranian Cucurbita (Cucurbita pepo L.) accessions, using genomic SSRs and implications for their breeding potential. Biochemical Systematics and Ecology 50: 187-198.

Bulut MÇ, Yüksel Özmen C, Ergül A, Ayanoğlu F (2018). Genetic characterization of Bay Laurel (Laurus nobilis L.) populations using microsatellite markers and flow cytometry. Mustafa Kemal Üniversitesi Ziraat Fakültesi Dergisi 23(2): 242-253.

Coskun OF, Gülşen O, Dalda-Şekerci A, Yetişir H, Pinar H (2017) Bazı çerezlik kabak hatlarında SSR markır analizi. Akademik Ziraat Dergisi 6: 151-156.

Dice LR (1945) Measures of the amount of ecologic association between species. Ecology 26(3): 297-302.

Doyle JJ, Doyle JL (1990) Isolation of plant DNA from fresh tissue. Focus 12: 13-15.

Ermiş S (2010) Ekolojinin kabuklu ve kabuksuz çekirdek kabak (Cucurbita pepo L.) hatlarında tohum verimi ve çerezlik kalitesine etkisi. Ankara Üniversitesi Fen Bilimleri Enstitüsü, Bahçe Bitkileri Anabilim Dalı, Doktora Tezi, Ankara, $153 \mathrm{~s}$.

Esmailnia E, Arefrad M, Shabani S, Karimi M, Vafadar F, Dehestani A (2015) Genetic diversity and phylogenetic relationship of Iranian indigenous cucurbits investigated by Inter Simple Sequence Repeat (ISSR) markers. Biharean Biologist 9(1): 47-54. Article No.: 141131. Romania.

Ferriol M, Pico B, Nuez F (2003) Genetic divercity of agermplasm collection of Cucurbita pepo using SRAP and AFLP markers. Theor. Appl. Genet. 107: 271-282.

Gulsen O, Roose M (2001) Lemons: Diversity and relationships with selected citrus genotypes as measured with nuclear genome markers. J. Amer.
Soc. Hort. Sci. 126(3): 309-317.

Gupta M, Chyi YS, Romero-Severson J, Owen JL (1994) Amplification of DNA markers from evalutionarily diverse genomes using single primers of simplesequence repeats. Theor. Appl. Genetics 89: 9981006.

Inan N, Yildiz M, Sensoy S, Kafkas S, Abak K (2012) Efficacy of ISSR and SRAP techniques for molecular characterization of some cucurbita genotypes including naked (hull-less) seed pumpkin. Journal of Animal and Plant Sciences 22(1): 126-136.

Joshi SP, Gupta VS, Aggarwal RK, Ranjekar PK, Brar DS (2000) Genetic diversity and phylogenetic relationship as revealed by inter simple sequence repeat (ISSR) polymorphism in the genus Oryza. Theor. Appl. Genet. 100: 1311-1320.

Karaman K, Dalda-Şekerci A, Yetişir H, Gülşen O, Coskun OF (2018) Molecular, morphological and biochemical characterization of some turkish bitter melon (Momordica charantia L.) genotypes. Industrial Crops and Products 123: 93-99.

Katzir N, Tadmor Y, Tzuri G, Leshzehhen E, Mozes-Daube N, Danin-Poleg Y, Paris HS (2000) Further ISSR and preliminary SSR analysis of relationship among accession of Cucurbita pepo. Acta Hort. 510: 433-439.

Michael NV, Moon P, Fu Y, Meru G (2019) Genetik diversity among accessions of Cucurbita pepo resistant to Phytophthora crown rot. American Society for Horticultural Science 17-22.

Ovesna J, Polakova K, Leisova L (2002) DNA analyses and their applications in plant breeding. Czech J. Genet. Plant Breed. 38(1): 29-40.

Paris HS (2005) The genes of pumpkin and squash. Hortscience 40: 1620-1630.

Pinar H, Coskun OF, Uysal E, Gülşen O, Yetişir H (2017a) Yöresel cırgalan biberi genotiplerinin ISSR markırları ile karakterizasyonu. Akademik Ziraat Dergisi 6: 145150.

Pinar H, Coskun OF, Uysal E, Gülşen O, Yetişir H (2017b) Farklı yamula patlıcanı genotiplerinin genetik benzerliklerinin ISSR moleküler markır yardımıyla belirlenmesi. Akademik Ziraat Dergisi 6: 157-162.

Röder MS, Huang XO, Ganal MW (2004) Wheat microsatellites: potantiel and implications. Berling Heidelberg p: 255-266.

Röder MS, Plaschke P, Konig SU, Borner A, Sorrells ME, Tanksley SD, Ganal MW (1995) Abundance, variability and chromosomal location of microsatellites in wheat. Mol. Gen. Genetics 246: 327-333.

Sarı N, Tan A, Yanmaz R, Yetisir H, Balkaya A, Solmaz I, Aykas L (2008) General status of cucurbit genetic resources in Turkey, pp. 21-32. Cucurbitaceae 2008, 
Proceedings of the IXth EUCARPIA meeting on genetics and breeding of Cucurbitaceae, May 21-24, 2008, Avignon (France).

Tecirli T, Dalda-Şekerci A, Coskun OF, Gülşen O (2018) Morphological and molecular diversity among Heliotropium greuteri samples. Erciyes Üniversitesi Fen Bilimleri Enstitüsü Fen Bilimleri Dergisi 34: 1-7.

Uzun A, Cil A, Yaman M, Coskun OF (2020) Genetic diversity and some fruit characteristics of quince genotypes collected from Kayseri region. Turkish Journal of Agriculture - Food Science and Technology 8(2): 318-323.

Uzun A, Coskun OF, Yaman M, Pinar H, Paris K (2017) Identification of genetic similarities among walnut (Juglans regia L.) genotypes selected from central anatolia region of Turkey with SRAP markers. Alatarım 16: 26-34.

Xanthopoulou A, Ganopoulos I, Psomopoulos F, Manioudaki M, Moysiadis $T$, Kapazoglou A, Osathanunkul M, Michailidou S, Kalivas A, Tsaftaris A (2017) De novo comparative transcriptome analysis of genes involved in fruit morphology of pumpkin cultivars with extreme size difference and development of EST-SSR markers. Gene 622: 50-56.
Xanthopoulou A, Ganopoulos I, Tsaballa A, NianiouObeidat I, Kalivas A, Tsaftaris A, Madesis P (2014) Summer squash identification by High-ResolutionMelting (HRM) analysis using gene-based EST-SSR molecular markers. Plant Molecular Biology Reporter 32(2): 395-405.

Yanmaz R, Düzeltir BK (2004) Kabak çekirdeğinin (Cucurbita pepo L.) besin değeri ve sanayide kullanım olanakları. Popüler Bilim Dergisi 11(125): 19-24.

Yanmaz R, Tuncer B, Eyduran E (2008) Çekirdek kabaklarında (Cucurbita pepo L.) meyve şekli ve ağırlığı ile tohum verimi ilişkisi. Türkiye III. Tohumculuk Kongresi, s 47- 51, Nevşehir.

Zietkiewicz E, Rafalski A, Labuda D (1994) Genome fingerprinting by simple sequence repeats (SSR)anchored PCR amplification. Genomics 20: 176-183. 